\title{
Corrigendum: Agrp neuron activity is required for alcohol-induced overeating
}

Sarah Cains, Craig Blomeley, Mihaly Kollo, Romeo Rácz \& Denis Burdakov

Nature Communications 8:14014 doi: 10.1038/ncomms14014 (2017); Published 10 Jan 2017; Updated 19 May 2017

The original version of this Article contained an error in the email address of the corresponding author Sarah Cains. The correct email is cains@hotmail.co.uk. The error has been corrected in the HTML and PDF versions of the Article.

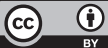

This work is licensed under a Creative Commons Attribution 4.0 International License. The images or other third party material in this article are included in the article's Creative Commons license, unless indicated otherwise in the credit line; if the material is not included under the Creative Commons license, users will need to obtain permission from the license holder to reproduce the material. To view a copy of this license, visit http://creativecommons.org/licenses/by/4.0/

(C) The Author(s) 2017 